\title{
Serological investigation of antibodies against respiratory viruses in calves from Brazilian family farming and their relation to clinical signs of bovine respiratory disease ${ }^{1}$
}

\author{
Natália C. Gaeta ${ }^{2 *}$, Bruno L.M. Ribeiro², Mario A.R. Alemán², \\ Eidi Yoshihara ${ }^{3}$, Eduardo C. Marques², Adriana N. Hellmeister ${ }^{4}$, \\ Edviges M. Pituco ${ }^{4}$ and Lilian Gregory ${ }^{2}$
}

\begin{abstract}
Gaeta N.C., Ribeiro B.L.M., Alemán M.A.R., Yoshihara E., Marques E.C., Hellmeister A.N., Pituco E.M. \& Gregory L. 2018. Serological investigation of antibodies against respiratory viruses in calves from Brazilian family farming and their relation to clinical signs of bovine respiratory disease. Pesquisa Veterinária Brasileira 38(4):642-648. Departamento de Clínica Médica, Faculdade de Medicina Veterinária e Zootecnia, Universidade de São Paulo, Avenida Prof. Dr. Orlando Marques de Paiva 87, Cidade Universitária, São Paulo, SP 05508 270, Brazil. E-mail: lgregory@usp.br

Bovine respiratory disease (BRD) is responsible for economic losses in cattle production. Viruses are categorized as primary etiological agents. The aims of this study were to evaluate the presence of antibodies against bovine viral diarrhea virus (BVDV), bovine herpes virus type 1 (BoHV-1), and bovine respiratory syncytial virus (BRSV) in healthy and BRD calves from family farming in relation to clinical signs of BRD. Hundred and forty-five calves were randomly selected and physical examination was performed. Only 123 animals were classified as healthy and BRD calves. Antibodies were evaluated by virus neutralization test. Person's Chi-square test and Fisher's exact test were performed as univariate analysis. Binary Logistic Regression was applied as multivariate analysis. Variables with $P<0.10$ were considered statistically significant. Variables with $0.15<P<0.10$ were considered as statistical tendencies. Antibodies against BoHV-1, BVDV, and BRSV were detected in 32\%, 23\% and $37 \%$ animals. Antibodies against both three viruses were detected in $26.8 \%$ of calves. The presence of antibodies against BRSV were associated to normal heart rates $(P=0.018)$ and unilateral airflow $(P=0.035)$. Tendency was observed to unilateral airflow $(P=0.06)$ Statistical tendencies were observed to Ab-BoHV-1 and body temperature $(P=0.119)$ and breathing pattern $(P=0.123)$. The profile of antibodies against respiratory viruses in calves from Brazilian family farming was firstly described. The results confirmed the importance of some clinical signs to viral infection.
\end{abstract}

INDEX TERMS: Serology, antibodies, respiratory viruses, calves, cattle, bovine respiratory disease, BVDV, BRSV, BoHV-1, viroses.

\footnotetext{
${ }^{1}$ Received on January 20, 2017.

Accepted for publication on April 29, 2017.

${ }^{2}$ Departamento de Clínica Médica, Faculdade de Medicina Veterinária e Zootecnia, Universidade de São Paulo, Avenida Prof. Dr. Orlando Marques de Paiva 87, Cidade Universitária, São Paulo, SP 05508 270, Brazil. *Corresponding author: natalia.gaeta@hotmail.com

${ }^{3}$ Agência Paulista de Tecnologia dos Agronegócios, Departamento de Descentralização do Desenvolvimento, Pólo Regional de Desenvolvimento Tecnológico dos Agronegócios da Alta Sorocabana, Cx. Postal 298, Rod. Raposo Tavares Km 563, Presidente Prudente, SP 19015-970, Brazil.

${ }^{4}$ Laboratório de Viroses de Bovídeos, Instituto Biológico de São Paulo, Av. Conselheiro Rodrigues Alves 1252, Vila Mariana, São Paulo, SP 04014-900, Brazil.
}

RESUMO.- [Investigação sorológica de anticorpos contra vírus respiratórios em bezerros de propriedades familiares brasileiras e sua relação com os sinais clínicos da doença respiratória dos bovinos.] A doença respiratória dos bovinos (DRB) é responsável por importantes perdas econômicas para a produção bovina, com maior impacto na agricultura familiar. Os vírus são comumente caracterizados como agentes etiológicos primários devido a mudanças na mucosa respiratória, na produção de citocinas e no funcionamento do sistema imune. Os objetivos deste estudo transversal foram avaliar a presença de anticorpos contra o vírus da diarreia 
viral bovina (VDVB), herpes vírus bovino tipo 1 (HVbo-1) e vírus respiratório sincicial bovino (VRSB) em bezerros sadios e com DRB de assentamentos em associação com a presença sinais clínicos de DRB. Cento e quarenta e cinco animais foram randomicamente selecionados e exame físico foi realizado. Somente 123 animais foram classificados em sadios e com DRB. Anticorpos foram identificados pelo teste de virusneutralização. Teste de qui-quadrado e teste exato de Fisher foram utilizados como análise univariada. A análise multivariada foi realizada pela regressão binária logística com o método Backward conditional. Variáveis com $P<0,10$ foram considerados significantes. Variáveis com $0,15<P<0,10$ foram consideradas tendências. Anticorpos contra HVbo-1, VDVB e VRSB foram detectados em 32\%, 23\% e 37\% dos animais. A presença concomitante de anticorpos contra os três vírus foi detectada em $26,8 \%$ dos bezerros. A presença de anticorpos contra VRSB foi associada à frequência cardíaca normal $(P=0,018)$ e fluxo de ar nasal unilateral $(P=0,035)$. Tendência estatística observada para anticorpos contra VDVB temperatura corporal $(P=0,119)$ e padrão respiratório $(P=0,123)$. Ao nosso conhecimento, este é o primeiro estudo que objetivou a avaliação da presença de anticorpos contra VDVB, VRSB e HVbo-1 em bezerros de assentamentos do estado de São Paulo, Brasil e sua relação com as manifestações clínicas da DRB.

TERMOS DE INDEXAÇÃO: Sorologia, anticorpos, vírus respiratório, bezerros, bovinos, doença respiratória bovina, complexo respiratório bovina, VDVB, VRSB, HVbo-1, viroses.

\section{INTRODUCTION}

Bovine respiratory disease (BRD) is responsible for great economic losses in cattle production (USDA 2013), with major impact on family farming due to poor sanitary control. Viruses are commonly categorized as primary etiological agents of BRD, by changing respiratory mucosa, producing of cytokines and functioning of immune system cells (Bosch et al. 2013). Bovine viral diarrhea virus (BVDV), bovine herpes virus type 1 (BoHV-1), bovine respiratory syncytial virus (BRSV) are important species to the pathogenesis of BRD.

Bovine viral diarrhea virus (BVDV) belongs to family Flaviviridae and to Genus Pestivirus (ICTV 2014). BVDV is responsible for diarrhea, reproductive disorders, mucosal disease and pneumonia. Seroprevalence studies are frequently conducted on adults due to its importance as causative agent of reproductive disorders (Samara et al. 2004, Quincozes et al. 2007, Brito et al. 2010, Piovesan et al. 2013, Pasqualotto et al. 2015), while researches with calves showing respiratory diseases are uncommon.

Bovine Herpes Virus type 1 (BoHV-1), as well as BVDV, it is an important etiological agent of bovine reproductive disorders (infectious pustular vulvovaginitis and infectious balanoposthitis), in addition to respiratory diseases (infectious bovine rhinotracheitis - IBR). BoHV-1 belongs to Genus Varicellovirus, Family Herpesviridae, subfamily Alphaherpesvirinae, and Order Herpesvirales (ICTV 2014). BoHV-1 has the ability to lead latent infections. During stress periods (e.g. transportation, lactation and calving), the reactivation of the infection is observed, and the transmission of the virus (Ackermann \& Wyler 1984) occurs. Young calves are more susceptible to respiratory disease infection by BoHV-1, showing unspecific clinical symptoms such as fever, inappetence and depression, besides mucopurulent nasal discharge (Oliveira 2011). As well as BVDV, seroprevalence studies about BRD calves is uncommon, while same studies about adults are usual due to its importance for reproductive disorders. The prevalence of BoHV-1 in Brazilian herds ranges between 41,9\% and 92,95\% (Médici et al. 2000, Poletto et al. 2004).

Bovine Respiratory Syncytial Virus (BRSV) belongs to Order Mononegavirales, Family Paramyxoviridae and Genus Pneumovirus (ICTV 2014). Clinical signs of BRSV infection are milder in adults compared to calves. The infection is characterized by clinical signs frequently associated to other respiratory agents such as depression, fever, cough, anorexia, and tachypnea (Gershwin 2007). Although few studies reported BRSV infection in cattle (Driemeier et al. 1997), only one describes the occurrence of antibodies against BRSV in Brazil. In São Paulo State, Affonso et al. (2011) observed prevalence between $46 \%$ and $84 \%$, which suggests its importance to the respiratory diseases in this state.

According to São Paulo Land Institute Foundation (ITESP), milk production on family farming farms in São Paulo State, from 2010 to 2011 was 71.635 .36 liters. Family farming influences the local economy (Mazzini et al. 2011) since producers supply their milk to local dairies and indirectly produces new jobs every day.

Bovine respiratory disease affects all ages, especially young calves. Besides having few Brazilian studies that evaluated the prevalence of antibodies against the most important viruses related to the respiratory diseases, researches that estimated their prevalence in calves of family farming are not available. Thus, the aim of this cross-sectional study was to determine the antibodies against bovine viral diarrhea virus, bovine herpes virus type 1 , and bovine respiratory syncytial virus in healthy and BRD calves from family farming farms located in Caiuá, Presidente Epitácio and Mirante de Paranapanema, São Paulo State, Brazil in relation to clinical signs of BRD.

\section{MATERIALS AND METHODS}

The present study was conducted at the Laboratory of Bovide Viruses, Biologic Institute and at the Department of Internal Medicine, School of Veterinary Medicine and Animal Science, University of São Paulo, Brazil, from August 2014 until March 2016. All procedures were carried out in agreement with the guidelines Committee of Ethics on Animal Use (Protocol number: 7973040214).

Area definition. The State of São Paulo is located in the southeast region of Brazil $\left(21^{\circ} 49^{\prime} \mathrm{S} 49^{\circ} 12^{\prime} \mathrm{W}\right)$. It has 645 cities and a total area of $248,222,362 \mathrm{Km}^{2}$. The cattle population is 10.126 .223 animals, from which 1,287,509 are dairy cattle (IBGE 2014). Pontal do Paranapanema is located in the extreme west region of the São Paulo State. It has 32 municipalities with family farming distributed along the region. The present study was carried out in Caiuá $\left(21^{\circ} 49^{\prime} 55^{\prime \prime} \mathrm{S}\right.$

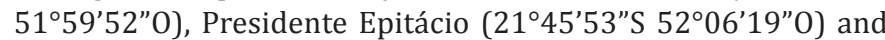
Mirante de Paranapanema(22¹7'31"S 5154'21"0), important cities located in Pontal do Paranapanema.

Animals and case definition. Hundred and forty-five male and female mongrel dairy calves with 1 to 12 -months-old from 42 semi-extensive farms were enrolled in this study. Calves and farms were randomly selected. Each farm has different number of calves, but same management. Calves received colostrum immediately after birth and remain with mothers during their life. After weaning (60 days), animals received pasture and mineral salt 
base diet. Mostly herds received vaccination against clostidiosis, foot-and-mouth disease and brucelosis. No vaccination against respiratory viruses was performed. Calves were randomly selected in each farm and they were classified as healthy and BRD calves after physical examination. BRD was defined when calves showed two or more of the following clinical signs (Benesi et al. 2013, Lima et al. 2016, Gaeta et al. 2017): mucopurulent or purulent nasal discharge, cough, crackle/snoring/whistle, respiratory rate $>40$ breaths $/ \mathrm{min}$ and rectal temperature $>39.5^{\circ} \mathrm{C}$. An experienced veterinarian member of our research team performed the physical examination in all calves.

Total blood collection. Eight mililiters of total blood was obtained by jugular vein punction using a dry BD vacutainer ${ }^{\circledR}$ tube. All tubes were centrifuged at $600 \mathrm{xg}$ for 15 minutes and the serum obtained was stored in tubes at $-20^{\circ} \mathrm{C}$ until processing.

Virus neutralization for BVDV, BoHV-1 and BRSV. Serum diagnosis to BVDV and BoHV-1 was performed by virus neutralization (VN) according to OIE (2004). Antibodies against BRSV were also detected by virus neutralization, but according to Affonso (2012). Serological response was evaluated in relation to BVDV-Ia NADL strain, BoHV-1 Los Angeles strain and ATCC VR-1485 incubated in Madin-Darby Bovine Kidney cells (MDBK) in 96 well plates. All plates were analyzed after incubation at $37^{\circ} \mathrm{C} / 5 \% \mathrm{CO}_{2}$. Antibody titers were expressed as the inverse of the dilution that the absence of cytopathic effect was observed. Samples with titers equal or higher than three were considered reactive. VN tests were validated through the control of negative and positive sera anti-BVDV antibodies, control of cells, and retrotitration ( $\left.\log _{10}\right)$, according to Reed-Muench method (1938). All tests were performed at the Laboratory of Bovine Viruses, Biologic Institute, São Paulo, Brazil. Laboratory personnel were blinded to calves classification.

Statistical analysis. Descriptive results were determined by relative and absolute frequencies. Pearson's chi-square test and Fisher's exact test were applied to evaluate the association between the presence of antibodies against BVDV, BoHV-1 and BRSV and health status (healthy and BRD calves), besides the clinical signs of BRD. Binary logistic regression with Backward conditional method was also performed. Variables related to clinical signs were grouped to obtain more significant analysis (altered nasal discharge: mucopurulent or purulent; altered percussion: coarse and thin crackle, whistle, and snoring; altered percussion: submassive or massive sounds). Odds Ratio was also determined. Analyzes were performed using SAS (SAS Institute Inc., NC). Variables with $P<0.10$ were considered statistically different. Variables with $0.15<\mathrm{P}<0.1$ were considered as statistical tendencies.

\section{RESULTS}

Serum diagnosis to BVDV, BRSV and BoHV-1 was performed in 145 samples, revealing 23\% (34/145), 37\% (54/145) and $32 \%$ (46/145) of reactive calves, respectively. The lack of some clinical information allowed the classification of 123 calves as healthy and BRD calves. No differences between healthy and BRD calves were detected to BoHV-1 $(P=0.281)$, BVDV $(P=0.982)$, and BRSV $(P=0.485)$. Calves showing antibodies against BRSV were numerically increased in BRD calves (Table 1).

The concomitant presence of antibodies against two or three viruses was observed in $22.8 \%$ calves, out of which BoHV-1+BRSV was numerically higher compared to the others (Table 2). The concomitant detection of antibodies against BVDV+BRSV was increased in BRD calves compared to healthy calves $(P=0.011)$. Antibodies against all three viruses were detected in healthy calves only.

The frequency of calves showing antibodies titers against BRSV and BoHV-1 were numerically increased between 2 and 16 . The highest titers (2048-8192) were noted in calves showing antibodies against BVDV, only (Table 3 ).

Table 4 shows the results from odds ratio and Chi-square test /Fisher's exact test. The variables of heart rates $(P=0.024)$, and unilateral airflow $(P=0.068)$ were selected for multivariate analysis. Statistical tendencies were observed to Ab-BoHV-1 and body temperature $(P=0.119)$ and breathing pattern $(P=0.123)$. In multivariate analysis, statistical significance was still observed for heart rate $(P=0.18)$ and airflow $(P=0.035)$.

Table 1. Antibodies against BVDV, BRSV and BoHV-1 according to health status of calves of family farming farms from Caiuá, Presidente Epitácio and Mirante de Paranapanema, São Paulo state, Brazil, 2016

\begin{tabular}{|c|c|c|c|c|c|}
\hline Antibodies & $\begin{array}{c}\text { Healthy } \\
\%(\mathrm{~N})\end{array}$ & $\begin{array}{c}\text { BRD } \\
\%(N)\end{array}$ & $\begin{array}{l}\text { Total } \\
\%(\mathrm{~N})\end{array}$ & OR (CI 90\%) & P-value \\
\hline BoHV-1 & $34.4(31 / 90)^{\mathrm{a}}$ & $24.2(08 / 33)^{\mathrm{a}}$ & $31.7(39 / 123)$ & $1.642(0.767-3.515)$ & 0.281 \\
\hline BVDV & $24.4(22 / 90)^{\mathrm{a}}$ & $24.2(08 / 33)^{\mathrm{a}}$ & $24.4(30 / 123)$ & $1.011(0.463-2.207)$ & 0.982 \\
\hline BRSV & $35.6(32 / 90)^{\mathrm{a}}$ & $42.4(14 / 33)^{\mathrm{a}}$ & $37.4(46 / 123)$ & $0.485(0.378-1.483)$ & 0.485 \\
\hline
\end{tabular}

${ }^{\mathrm{a}, \mathrm{b}}$ Different letters indicate statistical difference $(P<0.10)$.

Table 2. Simultaneous frequency of antibodies against BVDV, BRSV and BoHV-1 according to healthy status of calves reared in settlements of Caiuá, Presidente Epitácio and Mirante de Paranapanema, São Paulo state, Brazil, 2016

\begin{tabular}{|c|c|c|c|c|c|}
\hline Antibodies & $\begin{array}{c}\text { Healthy } \\
\%(\mathrm{~N})\end{array}$ & $\begin{array}{c}\text { BRD } \\
\%(N)\end{array}$ & $\begin{array}{c}\text { Total } \\
\%(\mathrm{~N})\end{array}$ & CI $(90 \%)$ & P-value \\
\hline BoHV-1+BRSV & $14.40(13 / 90)^{\mathrm{a}}$ & $6.10(02 / 33)^{a}$ & $12.20(15 / 123)$ & $0.729(0.188-2.833)$ & 0.350 \\
\hline BVDV+BRSV & $3.30(03 / 90)^{\mathrm{a}}$ & $18.20(06 / 33)^{\mathrm{b}}$ & $7.30(09 / 123)$ & $5.833(1.7111-9.886)$ & 0.011 \\
\hline BVDV+BoHV-1 & $4.40(04 / 90)^{\mathrm{a}}$ & $3.00(01 / 33)^{\mathrm{a}}$ & $4.10(05 / 123)$ & $0.729(0.111-4.777)$ & 1.000 \\
\hline BVDV+BoHV-1+BRSV & $5.60(05 / 90)^{\mathrm{a}}$ & $0.00(00 / 33)^{\mathrm{a}}$ & $4.10(04 / 123)$ & - & 0.573 \\
\hline Total & $22.20(20 / 90)$ & $27.30(09 / 33)$ & $22.80(28 / 123)$ & & \\
\hline
\end{tabular}

${ }_{\mathrm{a}, \mathrm{b}}$ Different letters indicate statistical difference $(P<0.10)$. 
Table 3. Antibody titers frequency according healthy status of calves from settlements in Caiuá, Presidente Epitácio and Mirante de Paranapanema, São Paulo state, Brazil, 2016

\begin{tabular}{lccr}
\hline \multicolumn{1}{c}{ Antibody titer } & $\begin{array}{c}\text { Healthy } \\
\%(\mathrm{~N})\end{array}$ & $\begin{array}{c}\text { BRD } \\
\%(\mathrm{~N})\end{array}$ & $\begin{array}{c}\text { Total } \\
\%(\mathrm{~N})\end{array}$ \\
\hline BoHV-1 & & & $68(84 / 123)$ \\
Negative & $65(59 / 90)$ & $76(25 / 33)$ & $19(24 / 123)$ \\
$2-16$ & $20(18 / 90)$ & $18(06 / 33)$ & $09(11 / 123)$ \\
$32-128$ & $10(09 / 90)$ & $06(02 / 33)$ & $03(04 / 123)$ \\
$256-1024$ & $04(04 / 90)$ & - & - \\
$2048-8192$ & - & - & $76(93 / 123)$ \\
BVDV & $75(68 / 90)$ & $76(25 / 33)$ & $03(04 / 123)$ \\
Negative & $03(03 / 90)$ & $03(01 / 33)$ & $12(15 / 123)$ \\
$2-16$ & $13(12 / 90)$ & $09(03 / 33)$ & $06(08 / 123)$ \\
$32-128$ & $05(05 / 90)$ & $09(03 / 33)$ & $02(03 / 123)$ \\
$256-1024$ & $02(02 / 90)$ & $03(01 / 33)$ & $62(76 / 123)$ \\
$2048-8192$ & $64(58 / 90)$ & $54(18 / 33)$ & $35(43 / 123)$ \\
BRSV & $32(29 / 90)$ & $42(14 / 33)$ & $03(04 / 123)$ \\
Negative & $03(03 / 90)$ & $03(01 / 33)$ & - \\
$2-16$ & - & - & -
\end{tabular}

Table 4. Antibodies against respiratory viruses in relation to clinical signs detected after physical examination of healthy and BRD calves

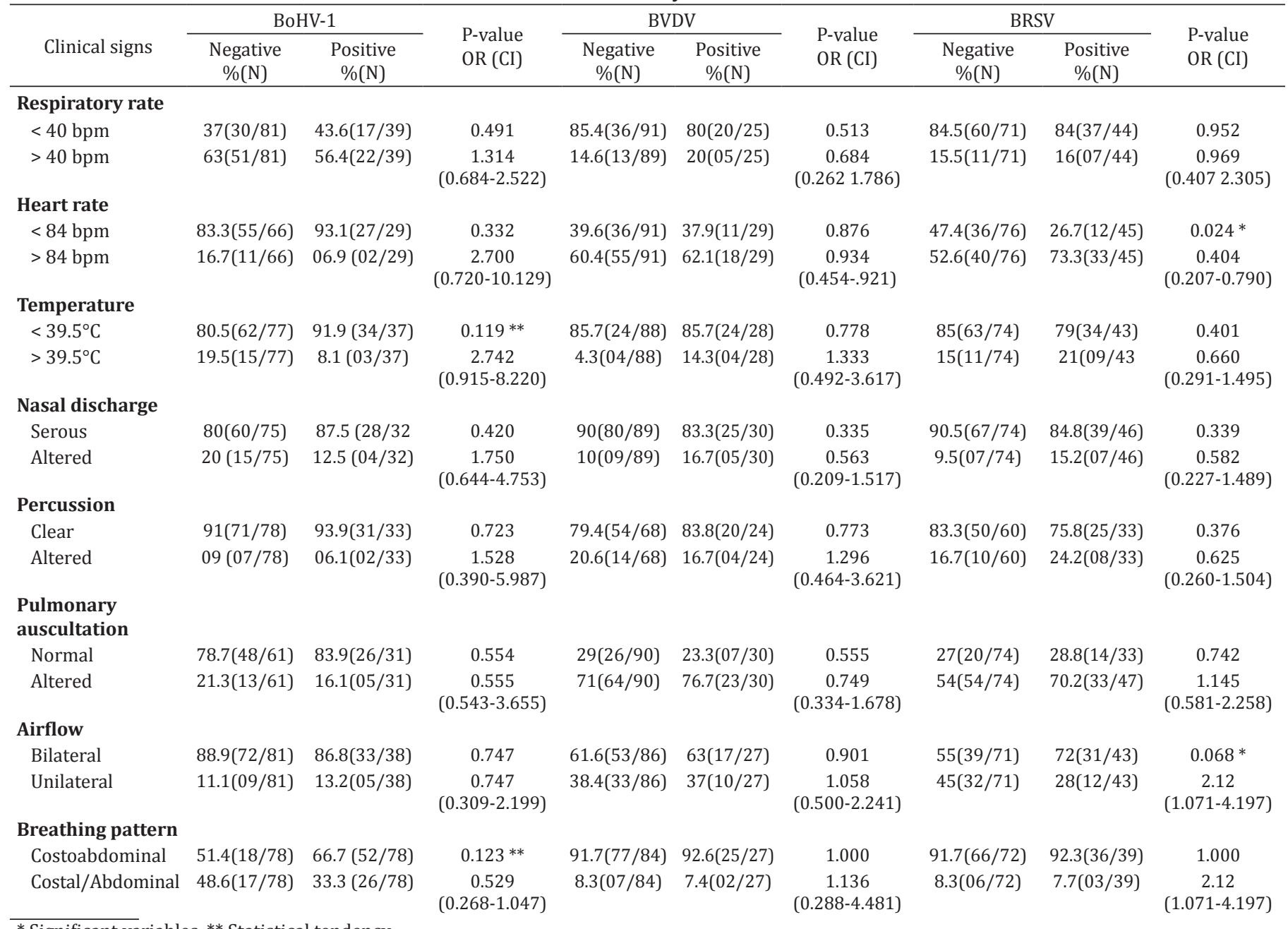

* Significant variables, ${ }^{* *}$ Statistical tendency. 


\section{DISCUSSION}

Viral infection are important determinant factor to respiratory infection due to significant changes in the respiratory environment (Bosch et al. 2013) and it is frequently reported as a predisposing factor to bacterial infections (Hartel et al. 2004, Autio et al. 2007).

In the present study, the prevalence of antibodies against BoHV-1 (Ab-BoHV-1) was 31.7\%. Results reported in the state of Rio Grande do Sul, Brazil, by Poletto et al. (2004), were similar to the present research (32.4\%). Lower frequencies were detected in the same state by Becker et al. (2015), in which study frequencies ranged from $26.4 \%$ in 2013 to $21.7 \%$ in 2014. Many studies have detected high frequencies of Ab-BoHV-1 in Brazil. In the Northeast region, Silva et al. (2015) and Sousa et al. (2013) detected prevalence of 79.5\% and 67.5\% in the states of Pernambuco and Maranhão, respectively. In the Center-south region, Oliveira et al. (2016) and Santos et al. (2014) reported prevalence of $61.4 \%$ and $66.75 \%$ in the states of São Paulo and Espírito Santo. The high frequency of animals with Ab-BoHV-1 in several Brazilian states could be related to the virus' ability to remain latent in the nerve ganglia, allowing its recurrent shedding and the maintenance of the infection inside the herd (Médici et al. 2000). As well as observed in Brazil, the occurrence of Ab-BoHV-1 outside the country is variable (Boelaert et al. 2000, Raaperi et al. 2010, 2014, Szeredi et al. 2010).

The prevalence of antibodies against BVDV (Ab-BVDV) observed in the present research was $24.4 \%$. Recent national studies showed higher occurrence compared to our results. In the States of São Paulo and Minas Gerais, Alexandrino et al. (2011) detected $69.70 \%$ of reagents. Chaves et al. (2010) reported $61.5 \%$ of animals showing Ab-BVDV in Maranhão. Piovesan et al. (2013) and Quincozes et al. (2007) detected $85.4 \%$ and $66.32 \%$ of reagents, respectively, in the State of Rio Grande do Sul. In Brazilian's central region, Brito et al. (2010) observed prevalence of $64 \%$ in the State of Goiás. In the Northeast, Fernandes et al. (2016) reported lower prevalence. Finally, Oliveira et al. (2016) reported 55.35\% of positive samples in São Paulo State, especially in healthy calves. On the other hand, higher frequencies in BRD calves were detected in the present study (33\%).

In our research, the occurrence of antibodies against BRSV (Ab-BRSV) was 37.4\%. Affonso et al., (2011) reported prevalence ranged from $45.61 \%$ to $84.42 \%$ in São Paulo State. In different locations in the same state, Oliveira et al. (2016) detected $93.10 \%$. In the South, Campalans \& Arns (1997), reported prevalence of $75 \%$. In order to evaluate the role of BRSV in cases of pneumonia in calves from the state of Minas Gerais, Flores et al. (2000) observed Ab-BRSV in 8/41 pulmonary tissue by indirect immunofluorescence.

Discrepancies between serological results observed in the present research and those reported elsewhere occurs due to differences between studied locations, production type, management, ages and diagnostic methods performed (Silva et al. 2015).

Many studies report the clinical signs of bovine respiratory disease by viral infection. Elvander (1996) described an outbreak of pneumonia in cattle by BRSV in Sweden. Animals showed fever, respiratory distress, coughing, a serous nasopharyngeal discharge, tearing and salivation. Similarly, a spontaneous BRSV infection in Brazilian cattle was described by Peixoto et al. (2000) who referred fever, dry cough and serous ocular discharge, besides loud and severe breathing sounds detected by pulmonary auscultation. In the present study, the presence of Ab-BRSV was associated to serous nasal discharge, confirming the importance of this clinical sign on BRSV infections. BVDV is considered a relevant predisposing factor to respiratory disease particularly by bacterial infection due to its ability to develop immunossuppression (Ridpath 2010). Many clinical signs of BRD showed by calves infected by BVDV are mostly due to secondary bacterial infection (Fulton et al. 2002). In the present research, calves showing abnormal sound on percussion were numerically increased in Ab-BVDV calves. On the other hand, a tendency to Ab-BVDV and normal pulmonary sounds on auscultation were detected. Finally, an experimental infection by BoHV-1 leads to red appearance of nasal mucosa, coughing and serous to mucopurulent nasal discharge (Muylkens et al. 2007). Results from the present study revealed a tendency to Ab-BoHV-1 and normal heart rates and unilateral nasal airflow. Abnormal nasal discharge signs were numerically more detected in calves with Ab-BoHV1. Besides, serous nasal discharge was also numerically more detected in Ab-BoHV-1 calves, confirming the possibility of observing both characteristics in infected calves.

\section{CONCLUSIONS}

To the best of our knowledge, this is the first study that aimed to evaluate the profile of antibodies against BVDV, BRSV and BoHV-1 in calves from Brazilian family farming.

The results contribute to better understand the epidemiology of these three viruses in Pontal do Paranapanema.

The results also confirmed the importance of some clinical signs to a specific infection, especially for BRSV.

The epidemiological and clinical studies should be expanded to better understand the role of the important microorganisms in the respiratory diseases of calves.

Acknowledgements.- We would like to thank São Paulo Research Foundation (protocol \#2014/03188-3) and Coordination of Improvement of Higher Education Personnel (CAPES) for the financial support, and to São Paulo Land Institute (ITESP) for the opportunity to study herds from settlements.

\section{REFERENCES}

Ackermann M. \& Wyler R. 1984. The DNA of an IPV strain of bovid herpesvirus 1 in sacral ganglia during latency after intravaginal infection. Vet. Microbiol. 9(1):53-63. http://dx.doi.org/10.1016/0378-1135(84)900786. PMid:6326378.

Affonso I.B., Gatti S.P., Alexandrino B., Oliveira M.C., Medeiros A.S.R., Buzinaro M.G. \& Samara S.I. 2011. Detection of antibodies against bovine respiratory syncytial virus (BRSV) in dairy cattle with different prevalences of bovine herpesvirus type 1 (BoHV-1) in São Paulo State, Brazil. Semina, Ciênc. Agrárias 32(1):295-300. http://dx.doi.org/10.5433/1679-0359.2011v32n1p295.

Affonso I.B., Gatti S.P., Medeiros A.S.R., Buzinaro M.G. \& Samara S.I. 2012. Atividade viral do vírus respiratório sincicial bovino (BRSV) em bezerros leiteiros. Ciênc. Anim. Bras. 13(2):253-258. http://dx.doi.org/10.5216/ cab.v13i2.10318.

Alexandrino B., Dias F.C., Oliveira M.C., Affonso I.B., Pereira G.T. \& Samara S.I. 2011. Herpesvirus bovino associado à diarreia viral bovina e à leucose enzoótica bovina. Ars Vet. 27(3):168-174.

Arns C.W., Campalans J., Costa S.C.B., Domingues H.G., D’Arce R.C.F., Almeida R.S. \& Coswig L.T. 2003. Characterization of bovine respiratory syncytial 
virus isolated in Brazil. Braz.J. Med. Biol. Res. 36(2):213-218. http://dx.doi. org/10.1590/S0100-879X2003000200008. PMid:12563523.

Autio T., Pohjanvirta T., Holopainen R., Rikula U., Pentikäinen J., Huovilainen A., Rusanen H., Soveri T., Sihvonen L. \& Pelkonen S. 2007. Etiology of respiratory disease in non-vaccinated, non-medicated calves in rearing herds. Vet. Microbiol. 119(2/4):256-265. http://dx.doi.org/10.1016/j. vetmic.2006.10.001. PMid:17084565.

Becker A.S., Rodrigues M.G., Olandin J.R., Menezes P.Q., Matos C.S., Wilsmann D.E., Viana A.E. \& Rodrigues P.R.C. 2015. Anticorpos neutralizantes contra o herpesvirus bovino tipo 1 e o vírus da diarreia viral bovina em bovinos vacinados e não vacinados da região sul do estado do Rio Grande do Sul. Sci. Anim. Health 3(2):209-220.

Benesi F.J., Bertagnon H.G., Wachholz L., Leal M.L.R., Fernandes W.R., Benites N.R. \& Melville P.A. 2013. Microbiota bacteriana e citologia da região traqueobrônquica de bezerros no período neonatal. Pesq. Vet. Bras. 33(6):700-704. http://dx.doi.org/10.1590/S0100-736X2013000600002.

Boelaert F., Biront P., Soumare B., Dispas M., Vanopdenbosch E., Vermeersch J., Raskin A., Dufey J., Berkvens D. \& Kerkhofs P. 2000. Prevalence of bovine herpesvirus-1 in the Belgian cattle population. Prev. Vet. Med. 45(3/4):285295. http://dx.doi.org/10.1016/S0167-5877(00)00128-8. PMid:10821966.

Bosch A.A.T.M., Biesbroek G., Trzcinski K., Sanders E.A.M. \& Bogaert D. 2013. Viral and bacterial interactions in the upper respiratory tract. PLoS Pathog. 9(1):e1003057. http://dx.doi.org/10.1371/journal.ppat.1003057. PMid:23326226.

Brito W.M.E.D., Alfaia B.T., Caixeta S.P.M.B., Ribeiro A.C.C., Miranda T.D.M.T., Barbosa A.C.V.C., Barthasson D.L., Linhares D.C. \& Faria B.0. 2010. Prevalência da infecção pelo Vírus da Diarréia Viral Bovina (BVDV) no Estado de Goiás, Brasil. Revta Patol. Trop. 39(1):7-20.

Chaves N.P., Bezerra D.C., Sousa V.E., Santos H.P. \& Pereira H.M. 2010. Frequência de anticorpos e fatores de risco para a infecção pelo vírus da diarreia viral bovina em fêmeas bovinas leiteiras não vacinadas na região Amazônica Maranhense, Brasil. Ciência Rural 40(6):1448-1451. http:// dx.doi.org/10.1590/S0103-84782010005000089.

Driemeier D., Gomes M.J.P., Moojen V., Arns C.W., Vogg G., Kessler L. \& Costa U.M. 1997. Manifestação clínico-patológica de infecção natural pelo Vírus Respiratório Sincicial Bovino (BRSV) em bovinos de criação extensiva no Rio Grande do Sul, Brasil. Pesq. Vet. Bras. 17(2):77-81. http://dx.doi. org/10.1590/S0100-736X1997000200006.

Elvander M. 1996. Severe respiratory disease in dairy cows caused by infection with bovine respiratory syncytial virus. Vet. Rec. 138(5):101-105. http:// dx.doi.org/10.1136/vr.138.5.101. PMid:8650902.

Fernandes L.G., Nogueira A.H., De Stefano E., Pituco E.M., Ribeiro C.P., Alves C.J., Oliveira T.S., Clementino I.J. \& Azevedo S.S. 2016. Herd-level prevalence and risk factors for bovine viral diarrhea virus infection in cattle in the State of Paraíba, Northeastern Brazil. Trop. Anim. Health Prod. 48(1):157165. http://dx.doi.org/10.1007/s11250-015-0937-x. PMid:26498460.

Flores E.F., Weiblen R., Medeiros M., Botton S.A., Irigoyen L.F., Driemeier D., Schuch L.F. \& Moraes M. 2000. A retrospective search for bovine respiratory syncytial virus (BRSV) antigens in histological specimens by immunofluorescence and immunohistochemistry. Pesq. Vet. Bras. 20(4):139-143. http://dx.doi.org/10.1590/S0100-736X2000000400002.

Fulton R.W., Cook B.J., Step D.L., Confer A.W., Saliki J.T., Payton M.E., Burge L.J., Welsh R.D. \& Blood K.S. 2002. Evaluation of health status of calves and the impact on feedlot perfomance: assessment of a retained ownership program for postweaning calves. Can. J. Vet. Res. 66(3):173-180. PMid:12146889.

Gaeta N.C., Lima S.F., Teixeira A.G., Ganda E.K., Oikonomou G., Gregory L. \& Bicalho R.C. 2017. Deciphering upper respiratory tract microbiota complexity in healthy calves and calves that develop respiratory disease using shotgun metagenomics. J. Dairy Sci. 100(2):1445-1458. http:// dx.doi.org/10.3168/jds.2016-11522. PMid:27988122.

Gershwin L.J. 2007. Bovine respiratory syncytial virus infection: immunopathogenic mechanisms. Anim. Health Res. Rev. 8(2):207-213. http://dx.doi.org/10.1017/S1466252307001405. PMid:18218161.
Härtel H., Nikunen S., Neuvonen E., Tanskanen R., Kivelä S.-L., Aho R., Soveri T. \& Saloniemi H. 2004. Viral and bacterial pathogens in bovine respiratory disease in Finland. Acta Vet. Scand. 45(3/4):193-200. http://dx.doi. org/10.1186/1751-0147-45-193. PMid:15663079.

IBGE 2014. Censo Agropecuário. Available in <www.ibge.org.br > Accessed on Apr 13, 2018.

ICTV 2014. International Committee on Taxonomy of Viruses. Available in <ictvonline.org> Accessed on Jan. 20, 2017.

Lima S.F., Teixeira A.G.V., Higgins C.H., Lima F.S. \& Bicalho R.C. 2016. The upper respiratory tract microbiome and its potential role in bovine respiratory disease and otitis media. Sci. Rep. 6(1):29050. http://dx.doi.org/10.1038/ srep29050. PMid:27363739.

Mazzini E.J.T., Martin E.S. \& Fernandes B.M. 2011. Assentamentos rurais no pontal do Paranapanema/SP: uma política de desenvolvimento regional. Revta Formação 14(1):56-66.

Médici K.C., Alfieri A.A. \& Alfieri A.F. 2000. Prevalência de anticorpos neutralizantes contra o herpesvírus bovino tipo 1 , decorrente de infecção natural, em rebanhos com distúrbios reprodutivos. Ciência Rural 30(2):347350. http://dx.doi.org/10.1590/S0103-84782000000200025.

Muylkens B., Thiry J., Kirten P., Schynts F. \& Thiry E. 2007. Bovine herpesvirus 1 infection and infectious bovine rhinotracheitis. Vet. Res. 38(2):181-209. http://dx.doi.org/10.1051/vetres:2006059. PMid:17257569.

OIE 2014. Manual of Diagnostic Tests and Vaccines for Terrestrial Animals 2014. Available in <http://www.oie.int/en/international-standard-setting/ terrestrial-manual/access-online/> Accessed on Apr. 13, 2018.

Oliveira B.A.D., Gaeta N.C., Ribeiro B.L.M., Alemán M.A.R., Marques L.M., Timenetsky J., Melville P.A., Marques J.A., Marvulle V. \& Gregory L. 2016. Determination of bacterial aetiologic factor on tracheobronchial lavage in relation to clinical signs of bovine respiratory disease. J. Med. Microbiol. 65(10):1137-1142. http://dx.doi.org/10.1099/jmm.0.000345. PMid:27582268.

Oliveira M.T. 2011. Detecçao de Herpesvirus bovino tipo 1 (BoHV-1) e tipo 5 (BoHV-5) em amostras de sêmen \& construção de um BoHV-5 com uma deleção do gene UL49.5. Dissertação de Mestrado em Microbiologia Agrícola e do Ambiente, Instituto de Ciências Básicas da Saúde, Universidade Federal do Rio Grande do Sul, Porto Alegre. 135p.

Pasqualotto W., Sehnem S. \& Winck C.A. 2015. Incidência de rinotraqueíte infecciosa bovina (IBR), diarreia viral bovina (BVD) e leptospirose em bovinos leiteiros da região oeste de Santa Catarina, Brasil. Revta Agroneg. Meio Amb. 8(2):249-270. http://dx.doi.org/10.17765/21769168.2015v8n2p249-270.

Peixoto P.V., Mota R.A., Brito M.F., Corbellini L.G., Driemeier D. \& Souza M.I. 2000. Infecção natural pelo Vírus Sincicial Respiratório Bovino (BRSV) no Estado de Alagoas. Pesq. Vet. Bras. 20(4):171-175. http://dx.doi. org/10.1590/S0100-736X2000000400008.

Piovesan M., Fernandes M.H.V., Corrêa R., Prado M.H.J., Camargo A.D. \& Rodrigues P.R.C. 2013. Anticorpos contra o herpesvírus bovino tipo 1, vírus da diarreia viral bovina e vírus da leucose enzoótica bovina na região da campanha do estado do Rio Grande do sul. Sci. Anim. Health 1:38-49.

Poletto R., Kreutz L.C., Gonzales J.C. \& Barcellos L.J.G. 2004. Prevalência de tuberculose, brucelose e infecções víricas em bovinos leiteiros do município de Passo Fundo, RS. Ciência Rural 34(2):595-598. http://dx.doi. org/10.1590/S0103-84782004000200043.

Quincozes C.G., Fischer G., Hübner S.D.O., Vargas G.D.A., Vidor T. \& Brod C.S. 2007. Prevalência e fatores associados à infecção pelo vírus da diarréia viral bovina na região Sul do Rio Grande do Sul. Semina, Ciênc. Agrárias 28(2):269-276. http://dx.doi.org/10.5433/1679-0359.2007v28n2p269.

Raaperi K., Nurmoja I., Orro T. \& Viltrop A. 2010. Seroepidemiology of bovine herpesvirus 1 (BHV1) infection among Estonian dairy herds and risk factors for the spread within herds. Prev. Vet. Med. 96(1/2):74-81. http://dx.doi. org/10.1016/j.prevetmed.2010.06.001. PMid:20598386.

Raaperi K., Orro T. \& Viltrop A. 2014. Epidemiology and control of bovine herpesvirus 1 infection in Europe. Vet. J. 201(3):249-256. http://dx.doi. org/10.1016/j.tvjl.2014.05.040. PMid:24954868. 
Ridpath J. 2010. The contribution of infections with bovine viral diarrhea viruses to bovine respiratory disease. Vet. Clin. N. Am., Food Anim. Pract. 26(2):335-348. http://dx.doi.org/10.1016/j.cvfa.2010.04.003. PMid:20619188.

Samara S., Dias F. \& Moreira S. 2004. Ocorrência da diarréia viral bovina nas regiões sul do Estado de Minas Gerais e nordeste do Estado de São Paulo Occurence of the bovine viral diarrhoea in the south region of the state of Minas Gerais and northeast region of the state of São Paulo. Braz. J. Vet. Res. Anim. Sci. 41(6):396-403. http://dx.doi.org/10.1590/S141395962004000600007.

Santos M.R., Ferreira H.C.C., Santos M.A., Saraiva G.L., Tafuri N.F., Santos G.M., Tobias F.L., Moreira M.A.S., Almeida M.R. \& Silva Júnior A. 2014. Antibodies against Bovine herpesvirus 1 in dairy herds in the state of Espirito Santo, Brasil. Revta Ceres 61(2):280-283. http://dx.doi.org/10.1590/S0034737X2014000200017.

Silva F.S., Oliveira J.M.B., Batista Filho A.F.B., Ribeiro C.P., Pituco E.M. \& Pinheiro Junior J.W. 2015. Análise soroepidemiológica da infecção pelo herpesvírus bovino tipo 1 (BoHV-1) em bovinos no estado de Pernambuco. Acta Scient. Vet. 43:1-11.

Sousa V.E., Bezerra D.C., Chaves N.P., Santos H.P. \& Pereira H.M. 2013. Frequency of antibodies against bovine viral diarrhea virus (BVDV) and bovine herpesvirus 1 (BoHV-1) in female dairy cattle production system in semi-intensive. Revta Bras. Med. Vet. 35(1):21-25.

Szeredi L., Jánosi S. \& Pálfi V. 2010. Microbiological and pathological examination of fatal calf pneumonia cases induced by bacterial and viral respiratory pathogens. Acta Vet. Hung. 58(3):341-356. http://dx.doi.org/10.1556/ AVet.58.2010.3.7. PMid:20713325.

USDA 2013. Feedlot 2011. IV. Health and Health Management on U.S. Feedlots with a Capacity of 1,000 or More Head. U.S. Departament of Agriculture, Animal and Plant Health Inspetion Service (APHIS), National Animal Health Monitoring System, Fort Collins. 109p 